\title{
A conversation with Bruce Alberts
}

$T_{\text {t }}$

he name Bruce Alberts is synonymous with the textbook Molecular Biology of the Cell, a text that has inspired legions of science students. Over the course of a storied career, Alberts (Figure 1), a professor at UCSF, made key insights into DNA replication, served as an academic leader on the national and international scene, and displayed an unwavering commitment to science education. For his advice about how to make room for yourself in a crowded field and how being the "small science guy" turned him into one of biggest science advocates, see the full interview on the JCI website at: http://www.jci.org/videos/cgms.

JCI: What were you like as a kid?

Alberts: I had little exposure to science. My father was a mechanical engineer who became a patent attorney, and my main frustration as a child was that he wanted me to help him fix everything. So instead of playing softball, which was my passion in those days, I had to install yet more wiring in the baseboards of our house so we wouldn't have extension cords anywhere. But I did learn from him a lot about tinkering and making things work and solving problems.

I never recognized until I was pretty advanced in college that science was a career that could be attractive or even that people got paid for doing science. I had really enjoyed chemistry in high school. I went to a back-to-school night that featured people talking about careers, and only two of the talks had anything to do with chemistry. One was a chemical engineer, who I still remember showed slides full of huge pipes coming out of oil company vats, which didn't seem very interesting. The other was a doctor who talked about the role of science in medicine. I went to Harvard College as a pre-med, thinking that that was the way to use science.

I had read Arrowsmith, which made the point that science was an iconoclastic endeavor, you had to fight all these bureaucracies, and you never had any money. Have things changed? I don't know.

JCI: Were you studious?

Alberts: I was surprised to do as well as I did in school. I was in the first class of
National Merit Scholarship winners, but I still remember taking the exam with a lot of other students who I thought were much smarter people than me.

I had never actually visited any colleges. My mother had heard of Harvard, so I had to go to Harvard if I got in. So I applied to Harvard and went as a pre-med major. My first biology course was in college.

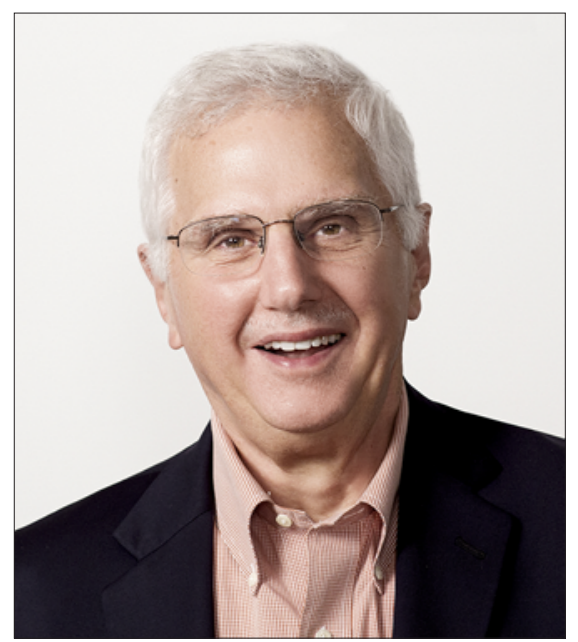

Figure 1. Bruce Alberts on September 22, 2016 in NYC. Image credit: Alexey Levchenko.

JCI: How did you veer away from becoming a medical doctor?

Alberts: Every science course at Harvard that I took had a lab associated with it. I was in the lab three hours a day at least three afternoons a week for my first three years. These labs were terrible. Nobody would ever want to be a scientist from taking those labs. They were just like cooking. I'm a big critic of why we continue to do this - you just learn how to follow instructions. In the second half of my third year, I was taking physical chemistry; it was actually one my favorite courses, but the lab was even worse than the other labs. I asked whether I could take the course without the lab, and they said, "You can only do that if you work in a research lab." Previously, nobody had told me I could work in a research lab for credit. To get out of the course lab, I worked with a famous chemist, Paul Doty, through his postdoc, Jacques Fresco, who later became a Princeton professor.

As I remember, at first it was very boring, much like the course labs, measuring the viscosity of a synthetic polymer solution. But when I spent the whole summer before my senior year in that lab - seven days a week, sixteen hours a day - Fresco gave me a real project, something that was actually challenging and interesting. After that summer, I decided not to apply to medical school and instead to pursue $\mathrm{PhD}$.

JCI: You failed your PhD exam. How do you recover from something like that?

Alberts: I was all ready to go for my postdoc. I had given up my apartment; I had a wife and a one-year-old baby. I had bought a car that was sitting in Geneva. It was pretty much a disaster. But it may have been the most important lesson for me about how to do science. I had been misled by my undergraduate research success, thinking that science was easy. It's actually very hard. What I learned from my failures in trying to create a theory and test it, my own theory of DNA replication, was that strategy is the most important thing in science. It's even more true now because there are billions of experiments you could do instead of millions. Most of them you should never do.

In talks to students, I emphasize that you could give me all of Rembrandt's paints, and what I would paint would be a mess. In the same sense, the tools for doing science are all there, but deploying them in a very skillful way is what you have to learn to do as a young scientist.

JCI: And you didn't give up. You designed better experiments and came back and wowed your committee.

Alberts: Well, I don't know if wowed them. I think they had not believed what I had reported. I did six more months of confirming experiments, and honestly, it wasn't much fun, and I don't think I learned anything important from that. But when I went for my postdoc in Switzerland, my science that year was carried out in a completely different way because I had failed my thesis. I decided, "I'm not going to try to make a hypothesis and prove my ideas. I'm going to develop a method that I know 
will be useful, and no matter what happens, it'll move science forward." My plan was to mobilize high concentrations of DNA on a column and thereby isolate a large number of proteins that we knew nothing about - proteins that likely functioned on DNA since they bound to it. You could purify them by eluting with a salt solution because DNA is negative and almost all proteins that bind to DNA display salt-sensitive binding. That was all known earlier. We also knew that even proteins that bind to specific sites, like transcription factors, bind much more weakly to any DNA sequence. So it was clear that making a column out of DNA would be useful for lots of people, even if nothing else was discovered by me.

My postdoc was spent figuring out how to make that column and then getting it to work. And, secondly, critically important, I met Dick Epstein, who was a professor in Geneva. I'd never heard of him before. But he had published a seminal paper two or three years earlier that I should have read as a graduate student - because if had I read it, it would have changed my bad strategy back then. He had worked with the model organism bacteriophage $\mathrm{T} 4$, one of the real mainstays of early molecular biology. He and colleagues at Caltech had carried out an extensive genetic analysis proving that there were at least seven genes in the genome of this large virus that were absolutely required to replicate the bacteriophage's DNA double helix. Given my past history of trying to see how DNA might be replicated by one enzyme, DNA polymerase, as soon as I read that paper by Epstein, my next 30 years of work were set - finding out exactly what these seven proteins do, which meant first purifying them.

JCI: How did you then get roped into writing and editing the landmark textbook Molecular Biology of the Cell?

Alberts: I knew Jim Watson as a younger faculty member at Harvard when I was there doing my thesis. In fact, I went to many of his lab meetings. In 1978, I got a phone call from Jim and Martin Raff. They had already recruited a team of three or four authors to write a textbook that would bring together the field of cell biology and the field of molecular biology. Jim said it would only take two months because he had already outsourced many chapters to experts and all we had to do was write a few chapters ourselves and then edit the experts' stuff. This was totally misleading.

It was a very depressing summer in 1979 when, after a year of work, we got back all these chapters written by experts that we were supposed to edit and we realized we couldn't use them. Most of them were not at the right level. In the end, we had to write it all ourselves and much of it was new to me.

JCI: You weren't really even familiar with the endoplasmic reticulum until you started on this textbook.

Alberts: And I was assigned to that chapter! However, Jim realized if I was going to write the chapter on endoplasmic reticulum that I didn't know anything about, I needed a coach. So [Nobel laureate] George Palade agreed to be my coach. This is before computers. I would send him this dribble I had written in typescript, and instead of saying, "This is dribble," he said, "Oh, this is very interesting. You may, however, want to know a few facts." And he'd direct me to ten papers to read and briefly say what they had discovered, which made it clear that what I had speculated was completely off base.

JCI: So at this point, you are a well-published scientist and author. You started getting drafted into more and more committee work, like chairing the committee on mapping and sequencing the human genome, and you were later asked to be the president of the National Academy of Sciences.

Alberts: It really started with a 1985 editorial I wrote for Cell after visiting Paris where my friend Mark Kirschner was on sabbatical and seeing/tasting the difference between French bread in small boulangeries and the junky Wonder Bread I was eating in America. So I wrote this editorial ["Small Science is Good Science"] talking about labs with ten people or less and explaining why I thought they were better. I got known as the "small science guy."

At that time, the genome project was being incubated. I had nothing to do with it. Most biologists were against it because it was big science. They already had the genome committee set up. It was Jim Watson, Sydney Brenner, Wally Gilbert, all these fantastic people who thought there should definitely be a genome project, but also many of the most severe critics - Shirley Tilghman and David Botstein. They got the idea they needed somebody neutral. I said, "Why me? I haven't thought about it." And they said, "That's why we want you."
But really, they also wanted me because I had written the small science editorial, so that if the committee came out with a strategy to go forward with a project, it wouldn't look like it was biased from the start by people who believed in big science. So in retrospect, if I hadn't written that 1985 editorial, I'd still be in a lab.

JCI: So we have Mark Kirschner and Parisian baguettes to thank for the genome.

Alberts: You could indeed thank baguettes for the start of my long career in science policy.

JCI: The presidency of the National Academy was a full-time job that required you to truly step away from the lab. How did you make that decision?

Alberts: I had told them before they chose me that I didn't want to be considered for that reason exactly - you had to move to Washington and really close your lab. I was working on a textbook in Connecticut in August 1992, and I got this telephone call, from Harry Gray, who's a great chemist with a wonderful personality from Caltech. And he said, "I know you didn't want to even be considered, but we've met and you're the only person for this job." They made the pitch to me that I could use the Academy to focus on science education. We were preparing the first-ever national science education standards at the time. I was on the committee, and I knew it was going terribly. I had been writing letters saying what a mess it was to the then president of the Academy. Basically Harry said, "If you don't take this job, you're going to mess up science education." The guilt was the strongest motivator.

I finally I said I'd do it for four years; I thought in four years, I could come back to UCSF, but my lab closed in three years. Anyway, in retrospect, I learned a lot at the Academy. We did do a lot of work on education, and the National Science Education Standards turned out really well.

JCI: You've mastered being a writer, an editor, a lobbyist, a politician, and a diplomat; if you couldn't be a scientist, do you think you could have pursued one of those careers?

Alberts: I would have enjoyed being a science journalist, but I only learned how to write by writing textbooks after spending years failing at that. I would enjoy being a science teacher if I was given the freedom to teach the way I want to teach.

\section{Ushma S. Neill}

